\title{
Occurrence of Listeria spp. in critical control points and the environment of Minas Frescal cheese processing
}

\author{
Isabella M.M. Silva $^{\text {a }}$, R.C.C. Almeida ${ }^{\text {a,* }}$, M.A.O. Alves ${ }^{\text {a }}$, P.F. Almeida ${ }^{\text {b }}$ \\ ${ }^{a}$ Universidade Federal da Bahia, Departamento de Ciência de Alimentos da Escola de Nutrição, Av. Araujo Pinho, \\ 32, Canela-CEP 40110-160, Salvador, Bahia, Brazil \\ ${ }^{\mathrm{b}}$ Departamento de Ciências da Biointeração do Instituto de Ciências da Saúde. Av. Araujo Pinho, \\ 32, Canela-CEP 40110-160, Salvador, Bahia, Brazil
}

Received 23 August 2001; received in revised form 21 January 2002; accepted 14 May 2002

\begin{abstract}
Critical control points (CCPs) associated with Minas Frescal cheese (a Brazilian soft white cheese, eaten fresh) processing in two dairy factories were determined using flow diagrams and microbiological tests for detection of Listeria monocytogenes and other species of Listeria. A total of 218 samples were collected along the production line and environment. The CCPs identified were reception of raw milk, pasteurization, coagulation and storage. Thirteen samples were positive for Listeria; 9 samples were Listeria innocua, 2 were Listeria grayi and 2 were L. monocytogenes. In factory A, Listeria was found in 50\% of raw milk samples, $33.3 \%$ of curd samples, $16.7 \%$ of pasteurized milk samples, $16.7 \%$ of cheese samples and $25 \%$ of rubber pipes used to transport the whey. The microorganism was not obtained from environmental samples in this plant. In factory B, Listeria was found in one sample of raw milk $(16.7 \%)$ and in three samples of environment $(17.6 \%)$ and L. monocytogenes was obtained from raw milk (16.7\%) and the floor of the cheese refrigeration room (14.3\%). Two serotypes, $4 \mathrm{~b}$ and $1 / 2 \mathrm{a}$, were observed among the strains of L. monocytogenes isolated, both which are frequently involved in outbreaks of food-borne listeriosis and sporadic cases of the disease all over the world.
\end{abstract}

(C) 2002 Elsevier Science B.V. All rights reserved.

Keywords: Listeria monocytogenes; Minas Frescal cheese; Critical control points; Environmental sampling

\section{Introduction}

Minas Frescal cheese is one of the most popular cheeses produced in Brazil. Produced from cow's milk, the major characteristic is the pleasant, slightly

\footnotetext{
${ }^{*}$ Corresponding author. Tel./fax: $+55-71-2450587$.

E-mail address: rogeriac@ufba.br (R.C.C. Almeida).
}

acid taste and rich flavour. Soft, white, fresh cheeses that are subject to minimal processing before packaging are highly perishable and thus have a short shelf life, even with refrigeration. Since Listeria monocytogenes is psychrotrophic and can grow at low temperatures, growth of this organism on contaminated cheese can occur.

L. monocytogenes is a food-borne pathogen that can contaminate dairy products (Menendez et al., 1997). Outbreaks of listeriosis resulting from con- 
sumption of dairy foods contaminated with $L$. monocytogenes have prompted concern about the behavior of this organism during processing and subsequent storage of various dairy products and about control of the hazard the bacterium poses to the dairy industry. Of particular importance is how milk, including that used to manufacture cheese and other cultured dairy products, can serve as a primary vehicle for transmission of the organism (Rosenow and Marth, 1987).

Although Listeria is inactivated under normal conditions of pasteurization (Schaack and Marth, 1988), problems can arise from postpasteurization contamination. Bacteria can enter cheese at many stages during its processing. The environmental diversity of dairy processing plants provides the microorganism with various sites for colonization. Any pathogen existing in raw milk can potentially make its way into the environment of plants processing cheese (Cotton and White, 1992).

In recent years, the hazard analysis critical control point (HACCP) concept has been proposed as the best approach to assure food safety. Inclusion of L. monocytogenes in the list of organisms subject to HACCP has recently driven the search for detection methods suitable for on-line monitoring (Almeida and Almeida, 2000). The concept of HACCP is a preventive, structured, systematic and documented approach to ensure food safety (Buchanan, 1990; Montarjemi et al., 1996). It is generally recognized that the production of cheeses with desirable organoleptic characteristics and which are safe for consumption can only be assured when certain factors are continuously controlled and tested: the microbiological quality of the raw milk; pasteurization of the raw milk prior to cheese production, prevention of recontamination after pasteurization of the milk and predominance of desirable microbial flora during storage (Zottola and Smith, 1993).

Despite the risk presented by L. monocytogenes in dairy products, there are few studies on the incidence of this microorganism at critical control points in the line of cheese processing in Brazil. Thus, the objectives of this work were to evaluate the hazard of Listeria species occurrence associated with Minas Frescal cheese processed in two factories in Bahia, Brazil and to assess the critical control points in the processing of this food.

\section{Materials and methods}

\subsection{Plants evaluated}

The factories studied in this work were located in Bahia (Brazil). Factory A uses approximately 10,000 1 of milk daily in cheese production while Factory B uses approximately 20001 daily.

\subsection{Determination of $C C P S$}

Flow diagrams of processing of Minas Frescal cheese were constructed in order to provide a clear, simple description of the steps involved in the process at the two factories (ICMSF, 1988).

To determine CCPs, the decision tree described by ONU/Organizacion Mundial de la Salud (OMS) (1991) was used.

\subsection{Sampling procedures}

During the study, seven visits were made to each factory between August 1999 and February 2000. Fifty-four food samples, 107 equipment samples, 22 worker handling samples and 35 environmental samples were taken.

Portions of $100 \mathrm{~g}$ or $100 \mathrm{ml}$ of food were aseptically collected at critical control points previously identified (Messer et al., 1992). Samples obtained from sites in plant areas including floors, drainage and wooden shelves were classified as "environmental" samples and those obtained from the product contact surfaces of utensils and equipment were classified as "equipment" samples. The samples of environment, equipment and worker handling surfaces were collected using the sponge method (Quevedo et al., 1977). Environmental samples were obtained by sponging an area approximately 2 by $3 \mathrm{ft}(0.6 \times 1.0 \mathrm{~m})$, whereas equipment samples were obtained by sponging the same area or a complete surface. All sponge samples were placed in sterile whirlpak bags, kept at $4{ }^{\circ} \mathrm{C}$, and processed within $24 \mathrm{~h}$ of collection.

\subsection{Laboratory procedures}

Sponges were tested for inhibitory properties against Listeria species (Daley et al., 1995). 
The sponges were transferred to sterile bags containing $100 \mathrm{ml}$ of University of Vermont modified Listeria enrichment broth (UVM, Difco) (Donnelly et al., 1992) with $0.5 \%$ sodium thiosulphate to neutralize chlorine compounds used for cleaning and incubated for $24-48 \mathrm{~h}$ at $30{ }^{\circ} \mathrm{C}$.

For the food samples, $25 \mathrm{~g}$ or $25 \mathrm{ml}$ of samples were blended with $225 \mathrm{ml}$ of Listeria enrichment broth (LEB, Difco) (Donnelly et al., 1992) and incubated for $24-48 \mathrm{~h}$ at $30{ }^{\circ} \mathrm{C}$.

After enrichment, all samples of food were plated on lithium chloride-phenylethanol-moxalactam medium containing ferric citrate ammoniac $0.05 \%$ and esculin $0.1 \%$, supplemented with antibiotics
(LPM, Difco) and Oxford medium (OXA, Difco) and incubated for $48 \mathrm{~h}$ at 30 and $35{ }^{\circ} \mathrm{C}$, respectively.

For equipment, worker handling and environmental testing, secondary enrichment was performed in Fraser broth. After this, blackened Fraser broth was streaked onto LPM and modified OXA (Difco) following incubation under the same conditions previously described. At the same time as the Fraser broth medium was inoculated, a loopful of each primary enrichment broth was also streaked onto a plate of modified OXA and LPM (Donnelly et al., 1992).

Five morphologically typical colonies from each plate producing a black halo from esculin hydrolysis

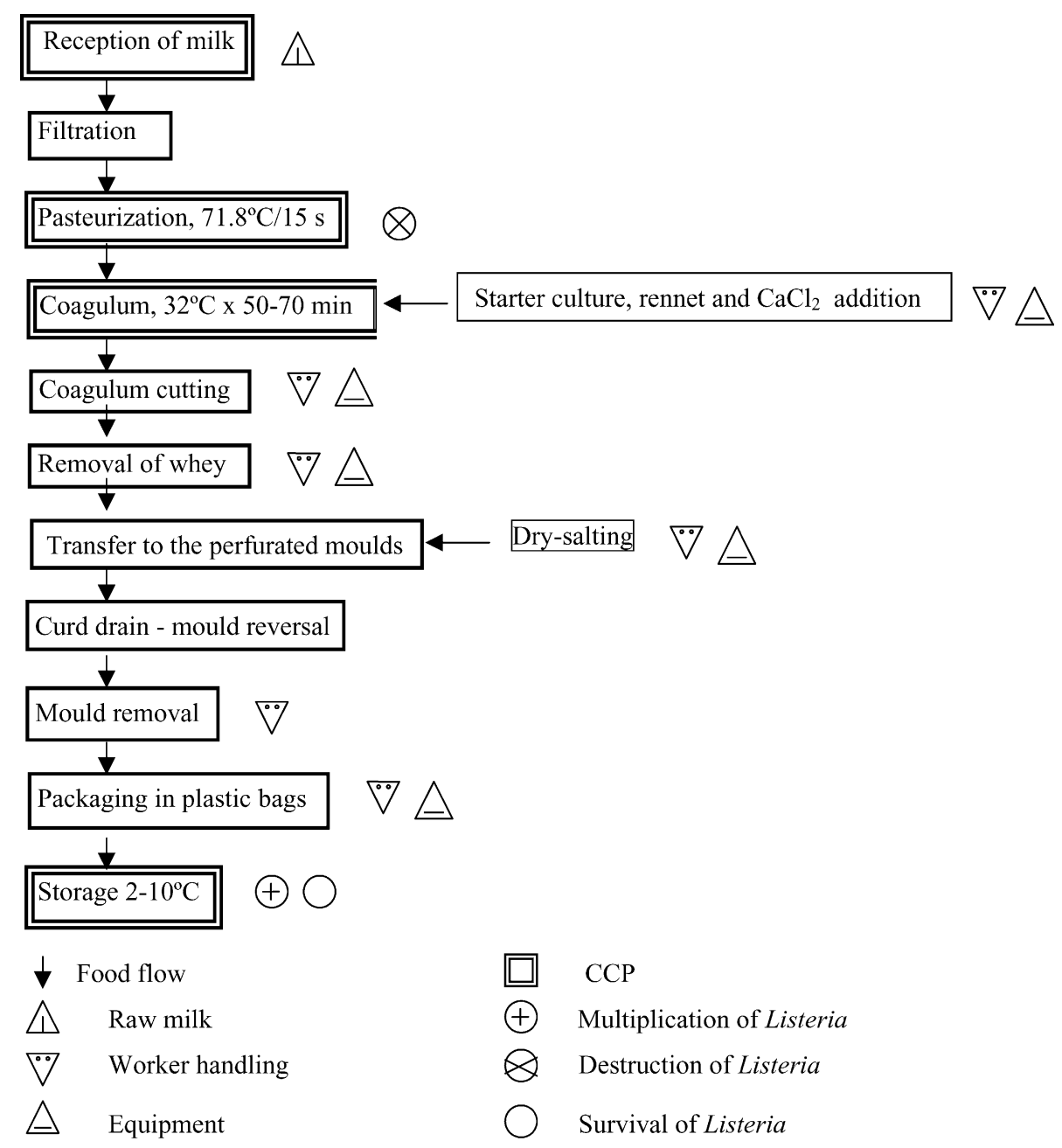

Fig. 1. Flow diagram of Minas Frescal cheese production and critical control points in factory A. 
were subjected to the following tests: Gram stain, tumbling motility at $21{ }^{\circ} \mathrm{C}$, catalase reaction, $\beta$ haemolysis on $5 \%$ horse blood agar plates, CAMP reaction with Staphylococcus aureus ATCC 25923 and Rhodococcus equi ATCC 33701, carbohydrate fermentation (rhamnose, xylose, mannitol, maltose and glucose), nitrate reduction and Voges-Proskauer test. L. monocytogenes Scott A serovar $4 \mathrm{~b}$, Listeria innocua (HPB 124), Listeria grayi (HPB 29), Listeria welshimeri (HPB 32) and Listeria seeligeri (HPB 62) provided by J.M. Farber, from Health Products and Food Branch of Health Canada, were used in control tests. Serological slide agglutination tests were done according to Seeliger and Hohne (1979) on all isolates presumed to be Listeria, using commercially prepared antisera (Difco).

\section{Results and discussion}

\subsection{Minas Frescal cheese flow diagrams}

Flow charts and critical control points for the processing of Minas Frescal cheese are presented in Figs. 1 and 2. Laboratory results are listed in Tables 1 and 2.

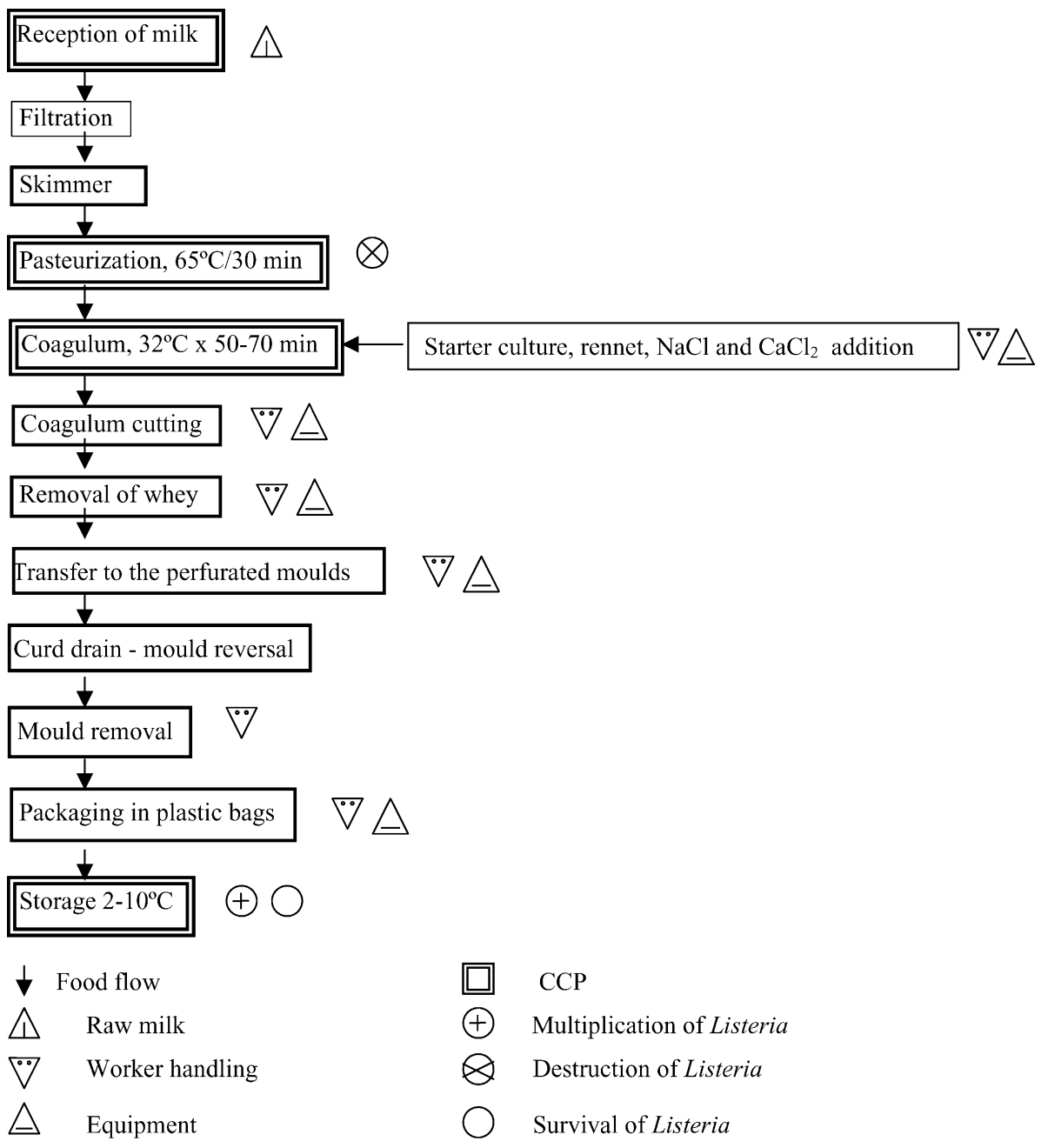

Fig. 2. Flow diagram of Minas Frescal cheese production and critical control points in factory B. 
Table 1

Incidence of Listeria in the processing of Minas Frescal cheese in factory A

\begin{tabular}{|c|c|c|c|}
\hline Samples & L. monocytogenes & L. inпосиа & L. grayi \\
\hline \multicolumn{4}{|l|}{$\begin{array}{l}\text { Reception and } \\
\text { pasteurization areas }\end{array}$} \\
\hline Raw milk $(6)^{\mathrm{a}}$ & 0 & 2 & 1 \\
\hline Pasteurized milk (6) & 0 & 1 & 0 \\
\hline Floor $(1)$ & 0 & 0 & 0 \\
\hline Drains (2) & 0 & 0 & 0 \\
\hline \multicolumn{4}{|l|}{$\begin{array}{l}\text { Cheese manufacturing } \\
\text { room }\end{array}$} \\
\hline Curd (6) & 0 & 1 & 1 \\
\hline Cheese (6) & 0 & 1 & 0 \\
\hline $\begin{array}{r}\text { Steam-jacketed } \\
\text { cheese vat }(6)\end{array}$ & 0 & 0 & 0 \\
\hline Stirrer (6) & 0 & 0 & 0 \\
\hline Knifes (7) & 0 & 0 & 0 \\
\hline Milk pipes (4) & 0 & 1 & 0 \\
\hline Cloths bags (6) & 0 & 0 & 0 \\
\hline Curd moulds (6) & 0 & 0 & 0 \\
\hline Lid moulds (6) & 0 & 0 & 0 \\
\hline Wire knifes (6) & 0 & 0 & 0 \\
\hline $\begin{array}{l}\text { Hands and } \\
\text { gloves (11) }\end{array}$ & 0 & 0 & 0 \\
\hline Floor (1) & 0 & 0 & 0 \\
\hline Drains (5) & 0 & 0 & 0 \\
\hline \multicolumn{4}{|l|}{$\begin{array}{l}\text { Cheese packaging } \\
\text { room }\end{array}$} \\
\hline Floor (1) & 0 & 0 & 0 \\
\hline Drains (2) & 0 & 0 & 0 \\
\hline \multicolumn{4}{|l|}{$\begin{array}{l}\text { Cheese refrigeration } \\
\text { rooms }\end{array}$} \\
\hline Wooden shelves (3) & 0 & 0 & 0 \\
\hline Floor (3) & 0 & 0 & 0 \\
\hline Totals (100) & 0 & 6 & 2 \\
\hline
\end{tabular}

${ }^{\mathrm{a}}$ Number of samples tested.

After milking, the raw milk was transported to the dairy factories at temperature of approximately 20-25 ${ }^{\circ} \mathrm{C}$ (factory A) and $21-31{ }^{\circ} \mathrm{C}$ (factory B). After reception, milk was filtered and pasteurized at 71.8 ${ }^{\circ} \mathrm{C} \times 15 \mathrm{~s}$ (factory A) or at $65{ }^{\circ} \mathrm{C} \times 30 \mathrm{~min}$ (factory B) and cooled to $32-36{ }^{\circ} \mathrm{C}$ (factory A) or $35-38{ }^{\circ} \mathrm{C}$ (factory B). At this temperature, a starter culture, rennet and $\mathrm{CaCl}_{2}$ were added and the milk coagulated in 50-70 min. The coagulum was cut using a $2-\mathrm{cm}$ wire knife, agitated for $20-30 \mathrm{~min}$ to separate the whey, transferred in thin layers into perforated moulds and then salt was added. The moulds were $15.5 \mathrm{~cm}$ in length and $11.0 \mathrm{~cm}$ in diameter. The curd was drained without pressing until firm enough to e removed remove from the moulds $(20-24 \mathrm{~h})$. The cheese was then packaged into plastic bags and stored at 2-10 ${ }^{\circ} \mathrm{C}$. The cheeses can be consumed 1 month after manufacture (Figs. 1 and 2). In factory $\mathrm{B}$ the raw milk was skimmed before pasteurization and $\mathrm{NaCl}$ was added with the rennet, $\mathrm{CaCl}_{2}$ and starter.

\subsection{Analysis of Minas Frescal cheese production CCPs}

Contamination of milk by L. monocytogenes can occur from mastitic animals and from environmental sources such as silage and soil during milking. Animal feed must be controlled because the presence of $L$.

Table 2

Incidence of Listeria in the processing of Minas Frescal cheese in factory B

\begin{tabular}{|c|c|c|c|}
\hline Samples & L. monocytogenes & L. innocua & L. grayi \\
\hline \multicolumn{4}{|l|}{$\begin{array}{l}\text { Reception and } \\
\text { pasteurization areas }\end{array}$} \\
\hline Raw milk $(6)^{\mathrm{a}}$ & 1 & 0 & 0 \\
\hline Skim milk (6) & 0 & 0 & 0 \\
\hline Pasteurized milk (6) & 0 & 0 & 0 \\
\hline Floor (1) & 0 & 0 & 0 \\
\hline Drains (1) & 0 & 0 & 0 \\
\hline \multicolumn{4}{|l|}{$\begin{array}{l}\text { Cheese manufacturing } \\
\text { room }\end{array}$} \\
\hline Curd (6) & 0 & 0 & 0 \\
\hline Cheese (6) & 0 & 0 & 0 \\
\hline $\begin{array}{r}\text { Steam-jacketed } \\
\text { cheese vat }(6)\end{array}$ & 0 & 0 & 0 \\
\hline Stirrer $(6)$ & 0 & 0 & 0 \\
\hline Milk pipes (6) & 0 & 0 & 0 \\
\hline $\begin{array}{l}\text { Sieves, pots and } \\
\text { jars (18) }\end{array}$ & 0 & 0 & 0 \\
\hline Curd mould (6) & 0 & 0 & 0 \\
\hline $\begin{array}{l}\text { Wire knifes and } \\
\text { knifes (12) }\end{array}$ & 0 & 0 & 0 \\
\hline Hands and gloves (11) & 0 & 0 & 0 \\
\hline Floor (3) & 0 & 0 & 0 \\
\hline Drains (4) & 0 & 0 & 0 \\
\hline \multicolumn{4}{|l|}{ Cheese packaging room } \\
\hline $\begin{array}{l}\text { Boxes and } \\
\text { plastic bags (12) }\end{array}$ & 0 & 0 & 0 \\
\hline Floor (1) & 0 & 0 & 0 \\
\hline Drains (1) & 0 & 0 & 0 \\
\hline \multicolumn{4}{|c|}{ Cheese refrigeration room } \\
\hline Wooden shelves (2) & 0 & 0 & 0 \\
\hline Floors (2) & 1 & 2 & 0 \\
\hline Drains (2) & 0 & 1 & 0 \\
\hline Totals (118) & 2 & 3 & 0 \\
\hline
\end{tabular}

${ }^{\text {a }}$ Number of samples tested. 
monocytogenes from improperly fermented silage has been documented (Fenlon, 1986). An increase in somatic cells indicates an unhealthy animal. Additional sources of contamination can occur from handling milk en route and at the dairy factory. The milk should be obtained from healthy animals under hygienic conditions. Cleaning and antisepsis of the udder and hands of the milkman before and after milking with appropriate antiseptics constitute preventive measures. Long exposure of milk to high temperatures during transportation may favour the growth of pathogens, including L. monocytogenes. Control of raw milk includes the determination of milk acidity, freezing point, antibiotic and metabolic residues (Mauropoulos and Arvanitoyannis, 1999). The reception of raw milk was a stage considered a CCP because the reception was carried out at ambient temperature and the product stood there for more than $2 \mathrm{~h}$. Controls of time and temperature in this stage should be established and systematically monitored to prevent creation of a hazard.

In a high-temperature short-time (HTST) system, the typical temperature-time conditions for pasteurization of milk are $72{ }^{\circ} \mathrm{C}$ for $15 \mathrm{~s}$ (Mauropoulos and Arvanitoyannis, 1999). The flow of milk into the pasteurizer cannot exceed the rate at which the 15 -s hold is measured. In 1985, the consumption of contaminated Jalisco brand Mexican-style cheese manufactured in California was directly linked to more than 142 cases of listeriosis, including 48 deaths (Linnan et al., 1988). According to the Center for Disease Control in the United States, a leak in the pasteurization of the milk used to produce the cheese was attributed to excessive volume of milk in the pasteurizer. Pasteurization must ensure that pathogenic microorganisms do not survive the process in order to reduce public health risk.

For Minas Frescal cheese, the coagulation step was considered a CCP because the temperature was controlled in order to promote the starter growth and the addition of the rennet. The preventive measures at this stage consist of monitoring the temperature of milk and controlling the development of acidity ( $\mathrm{pH}$ reaches 5.0-6.1 in factory A and 4.9-6.2 in factory B).

The other stages, such as coagulum cutting, removal of whey, transfer to the moulds and packaging were considered critical points because of the possibility of introduction of Listeria from utensils and worker handling. The storage of cheese $\left(2-8{ }^{\circ} \mathrm{C}\right)$ was considered a CCP because the reduced temperature delays the growth of L. monocytogenes.

\subsection{Occurrence of Listeria in CCPs and the environ- ment}

A total of 218 samples were collected and 13 different isolates of Listeria species were identified in both factories. The species most often isolated was L. innocua, which accounted for 9 of the $13(70 \%)$ isolates in both factories. Fifteen percent of the isolates were L. monocytogenes and the same percentage were L. grayi. L. monocytogenes was obtained from raw milk (serotype $4 \mathrm{~b}$ ) and the floor of the milk storage room (serotype 1/2a) in factory B (Table 2).

In factory $\mathrm{A}, 50 \%$ of the raw milk samples were Listeria positive and in factory B the bacteria was isolated in $16,7 \%$ of the raw milk samples.

L. innocua was detected in raw milk, pasteurized milk, curd and cheese and in the milk pipes used to transport the whey in the plant A (Table 1). In factory B, L. innocua was found in three samples taken from floors and drains of the cheese storage room and $L$. monocytogenes was found in one sample (Table 2).

Two serotypes, $4 \mathrm{~b}$ (raw milk) and 1/2a (floor) were observed among the strains of L. monocytogenes isolated in factory B. Both of these serotypes are frequently involved in outbreaks of food-borne listeriosis and sporadic cases of disease all over the world. The presence of L. monocytogenes in $16.7 \%$ of raw milk and in $14.3 \%$ of floor samples in plant B indicated the need for frequent monitoring at the milk pasteurization stage and during cleaning and sanitizing operations of equipment and environments in order to avoid the occurrence of cross contamination of the product.

Minas Frescal cheese has a low pH (4.9-5.3), high water activity and moisture levels $(55-58 \%)$ that could favor the survival of L. monocytogenes. Previous research conducted in Brazil by Destro et al. (1991) detected L. monocytogenes in $10 \%$ of manufactured Minas Frescal cheese, while Cassarotti et al. (1994) failed to detect Listeria in 20 samples of the same type of cheese.

According to results obtained by Silva et al. (1998), among the different types of cheese investigated in Brazil, Minas Frescal showed the highest 
frequency of L. monocytogenes, which was in 7 of the $17(41.17 \%)$ samples tested.

Of 107 samples taken from equipment from the two plants, only one $(0.9 \%)$ was positive for Listeria. Surface samples from workers' hands and gloves were negative for Listeria. In a study conducted by Menendez et al. (1997), only 3\% of samples taken from equipment in 18 cheese factories, were found to be positive.

An evaluation of plants in California producing milk products (Walker et al., 1991) revealed that $12 \%$ of the samples obtained from 39 different plants were contaminated with Listeria. Klausner and Donelly (1991) and Charlton et al. (1990) surveyed the environment of a variety of dairy plants including processing, fluid milk, frozen milk products, cheese and other cultured products. Both groups reported an overall incidence of Listeria ranging from $12.6 \%$ to $17.5 \%$.

In this study, we found Listeria in $11.4 \%$ of the samples from the environment; of these $2.9 \%$ were $L$. monocytogenes. In the Menendez study, the total percentage of environmental samples testing positive for Listeria spp. was $14.4 \%$, higher than that reported by Nelson (1990). However, percentages of positive samples of $L$. monocytogenes were similar, $2.4 \%$ by Menendez et al. (1997) and 2.2\% for the data obtained by Nelson (1990). Pritchard et al. (1995) evaluated the environment of plants processing fluid milk, cheese and noncheese cultured products and they identified Listeria in $35.3 \%$ of environmental samples tested.

The presence of Listeria species in the production line indicates that postprocessing contamination can occur. Therefore, every effort must be made to control this organism in cheese manufacturing by safer handling of raw milk, effective destruction of microorganisms through heat processing and proper cleaning and sanitation of CCPs to prevent recontamination of the heated product with L. monocytogenes. It is evident that development and use of the HACCP concept is urgently needed for all processing plants showing the degree and level of contamination observed in this study.

\section{Acknowledgements}

We are grateful to Dr. Ernesto Hofer (Brazil) for performing serological characterization of Listeria species and to Dr. J.M. Farber (Canada) for providing the strains of Listeria. CAPES, Brazil supported this study.

\section{References}

Almeida, P.F., Almeida, R.C.C., 2000. A PCR protocol using inl gene as a target for specific detection of Listeria monocytogenes. Food Control 11, 97-101.

Buchanan, R.L., 1990. Advances in cultural methods for the detection of Listeria monocytogenes. In: Miller, A.J., Smith, J.L., Somkuti, G.A. (Eds.), Food-Borne Listeriosis. Elsevier, New York, pp. 85-95.

Cassarotti, V.T., Gallo, C.R., Camargo, R., 1994. Ocorrência de Listeria monocytogenes em leite cru, leite pasteurizado tipo C e queijo Minas Frescal comercializados em Piracicaba-SP. Arch. Latinoam. Nutr. 44, 158-163.

Charlton, B.R., Kinde, H., Jensen, L.H., 1990. Environment survey for Listeria species in California milk processing plants. J. Food Prot. 53, 198-201.

Cotton, L.N., White, C.H., 1992. Listeria monocytogenes, Yersinia enterocolitica and Salmonella in dairy plant environments. J. Dairy Sci. 75, 51-57.

Daley, E.F., Pagotto, F., Farber, J.M., 1995. The inhibitory properties of various sponges on Listeria spp. Lett. Appl. Microbiol. 20, 195-198.

Destro, M.T., Serrano, A.M., Kabuki, D.I., 1991. Isolation of Listeria species from some Brazilian meat and dairy products. Food Control 2, 110-112.

Donnelly, C.W., Brackett, R.E., Doores, S., Lee, W.H., Lovett, J., 1992. Listeria. In: Vanderzant, C., Splitstoesser, D.F. (Eds.), Compendium of Methods for Microbiological Examination of Foods, 3rd ed. American Public Health Association, Washington, pp. $637-663$.

Fenlon, D.R., 1986. Rapid quantitative assessment of the distribution of Listeria in silage implicated in suspected outbreak of listeriosis in calves. Vet. Rec. 118, 240-242.

International Commission on Microbiological Specification for Foods, 1988. Microorganisms in Foods-Application of the hazard analysis critical control point (HACCP) system to ensure microbiological safety and quality. In: Silliker, J.H., BairdParker, A.C., Bryan, F.L., Christian, J.H.B., Roberts, T.A., Tompkin, R.B. (Eds.), 1988. Blackwell Scientific Publications, Oxford, 377 pp.

Klausner, R.B., Donelly, C.W., 1991. Environmental sources of Listeria and Yersinia in Vermont dairy plants. J. Food Prot. 54, 720-724.

Linnan, M.J., Mascola, L., Lou, X.D., May, S., Salminen, C., Hird, D.W., Yonekura, M.L., Hayes, P., Weaver, R., Audurier, A., Plikaytis, B.D., Fannin, S.L., Kleks, A., Broome, C.V., 1988. Epidemic listeriosis associated with Mexican-style cheese. N. Engl. J. Med. 319, 823-828.

Mauropoulos, A.A., Arvanitoyannis, I.S., 1999. Implementation of hazard analysis critical control point to Feta and Manoury cheese production lines. Food Control 10, 213-219. 
Menendez, S., Godinez, M.R., Rodriguez-Otero, J.L., Centeno, J.A., 1997. Removal of Listeria spp. in a cheese factory. J. Food Saf. 17, 133-139.

Messer, J.W., Midura, T.F., Peeler, J.T., 1992. Sampling plans, sample collection, shipment, and preparation for analysis. In: Vanderzant, C., Splitstoesser, D.F. (Eds.), Compendium of Methods for Microbiological Examination of Foods, 3rd ed. American Public Health Association, Washington, pp. 25-49.

Montarjemi, Y., Kaferstein, F., Moy, G., Miyagawa, S., Miyagishima, K., 1996. Importance of HACCP for public health and development. The role of the World Health Organization. Food Control 72, 77-85.

Nelson, J.H., 1990. Where Listeria likely to be found in dairy plants. Dairy Food Environ. Sanit. 10, 344-345.

ONU/Organizacion Mundial de la Salud (OMS), 1991. Definiciones y procedimientos generales del HACCP para su uso por el codex. Comission del codex alimentarius, Washington, p. 11.

Pritchard, T.J., Flanders, K.J., Donelly, C.W., 1995. Comparison of the incidence of Listeria on equipment versus environmental sites within dairy processing plants. Int. J. Food Microbiol. 26, 375-384.

Quevedo, F., Lasta, J.A., Dinelli, J.A., 1977. Control microbiologi- co de superficies con esponjas de poliuretano. Rev. Latinoam. Microbiol. 19, 79-82.

Rosenow, E.M., Marth, E.H., 1987. Listeria, listeriosis and dairy foods: a review. Cult. Dairy Prod. J. Am. Cult. Dairy Prod. Inst., $13-17$.

Schaack, M.M., Marth, E.H., 1988. Behavior of Listeria monocytogenes in skim milk during fermentation with mesophilic lactic starter cultures. J. Food Prot. 1, 600.

Seeliger, H.P.R., Hohne, K., 1979. Serotyping of Listeria monocytogenes and related species. In: Bergant, T., Norris, J. (Eds.), Methods in Microbiology. Academic Press, New York, pp. $33-48$.

Silva, M.C.D., Hofer, E., Tibana, A., 1998. Incidence of Listeria monocytogenes in cheese produced in Rio de Janeiro, Brazil. J. Food Prot. 61, 354-356.

Walker, R.L., Jensen, L.H., Kinde, H., Alexander, A.V., Owens, L.S., 1991. Environmental survey for Listeria species in frozen milk product plants in California. J. Food Prot. 54, 178-182.

Zottola, E.A., Smith, L.B., 1993. Growth and survival of undesirable bacteria in cheese. In: Fox, P.F. (Ed.), Cheese: Chemistry, Physics and Microbiology, 2nd ed., vol. 1. Chapman \& Hall, London, pp. 471-492. 